\title{
Right-wing radicalism is shaping the political agenda in the post-Soviet space
}

\section{Short communication}

The ideology of right-wing radicalism is becoming increasingly popular in Europe. The post-Soviet space is not an exception. The difference between the post-Soviet radicals and the European radicals is that the post-Soviet ones are a large systemic element in the political structure in many countries of the Former Soviet Union. Why?

Do not forget that for many residents of the former Soviet republics, the need for the collapse of the USSR was not obvious. At the referendum on March 17, 1991, almost $78 \%$ of the population was in favor of preserving the USSR. The decision to stop the project of the USSR was taken by the leaders of the Soviet republics behind the scenes, without a mandate from the people. Therefore, to create on this base the new nation state, the new society was very difficult task. Therefore, it was important for the new political leaders of the newly independent states (mostly of them were the functionaries of the former Soviet communist party) to justify the need for independence. Because of it there is no wonder that just the second president of Ukraine, Mr. Leonid Kuchma, even published in 2003 a book titled "Ukraine is not Russia". ${ }^{1} \mathrm{He}$ tried in this Book to substantiate the fact of the collapse of the Soviet Union, which ambiguously perceived in Ukraine, and the emergence of Ukraine as an independent State. He shares his views on the history of Ukraine, on the events of the $20^{\text {th }}$ and early 21 st centuries, sets out his point of view why Ukraine cannot be Russia, differences in Ukrainian and Russian national characters, different views on the cultural and historical past and mutual claims. During the presentation of the book, he stated: "We have the task on the agenda: to create a Ukrainian." The danger of not returning to their Ukrainianness is relevant for millions of Ukrainian citizens". ${ }^{2}$

It was possible to do this ("create an Ukrainian") solely due to the development of "Ukrainism" and Ukrainian culture, especially in the field of education, media and the government service at the expense of "Russianness" and Russian culture, which are widespread in the central and eastern part of Ukraine. The same situation is in some other countries, first of all Baltic states, Moldova, and now Kazakhstan and Central Asia. So, the former communist elite beeing in the powers of the new independent States, saw the path of the creating a Nation by reducing Russianness. Russianness could be reduced in two ways: by reducing the spread of Russian culture and by replacing heroesthe heroes of the Soviet period were to be replaced with anti-Russian heroes. For example, in Ukraine the heroes were written down by the Nazis from the Organization of Ukrainian Nationalists, who organized the Volyn massacre of the Poles in 1943-44, ${ }^{3}$ and before they actively participated in the murders of the Jewish population in Ukraine. ${ }^{4}$ So the heroes were found among the Waffen SS veterans in Latvia, Estonia and Ukraine. So the hero became the inspirer of Jewish pogroms in Ukraine during the Civil War in Russia 1917-22 Simon Petliura, ${ }^{5}$ and in Moldova - the Romanian marshal Antonescu, Hitler's ally in the World War II. ${ }^{6}$

Therefore, the main tasks of the governments of the new states just in the 90s. Were:
Volume 3 Issue 4 - 2019

\author{
Engel Valery Viktorovich \\ Department of radical rights, Moscow Institute of \\ Psychoanalysis, Russia
}

Correspondence: Engel Valery Viktorovich, Department of radical rights, Head of the Center for Monitoring and Comparative Analysis of Intercultural Communications at the Moscow Institute of Psychoanalysis, Russia, Tel +7(985)922-I463, Email engel@inpsycho.ru

Received: June 28, 2019 | Published: July 09, 2019

1. To split the Society by the revision history and by the opposing cultures of the majority and minority to each other;

2. Discrimination of the national and linguistic minorities;

3. Creation of a new Society based on the ethno-cultural values of the majority- by the forced assimilation of the minorities and, by encouraging of the minority emigration.

The political post communist elite saw this way like only one possibility to create and save a new country. In this situation, the right-wing radicals were their natural allies in that sense. As a result, these countries were divided along ethnic lines. This is most clearly manifested during the parliamentary elections when the Russians vote for the so-called "Russian parties", and representatives of the ethnic majority vote for "non-Russian parties". As a result of this vote over the past 27 years, the following fundamental decisions were taken:

1) Displacement of representatives of national minorities from the government structures on formal grounds (for example, due to insufficient knowledge of the state language) ${ }^{7}$

2) Creation the new Institute of non-citizenship like in Latvia and Estonia-non-citizens don't have a right to vote and have other 80 restrictions in the human rights; $;, 9$

3) A partly restrictions in the use of minority languages in school and by the communication with the authorities and just in public business like in Ukraine, Moldova and some Central Asia and Baltic countries;

4) The full destruction of the education system on the languages of national minorities like in Ukraine and Latvia; ${ }^{10-12}$

5) Discrimination of the languages of the national minorities. For example in April 2019 the Ukrainian Parliament adopted the Law of Languages. ${ }^{13}$ This is the Law of total Ukrainisation. In the field of state authorities, local government, state and municipal enterprises, the judicial system, the armed forces, law enforcement, elections and referendums, labor relations, education, science, culture, television and radio broadcasting, print media, etc. only Ukrainian can be used. Attempts to grant official status to another 
language are equated with actions aimed at forcibly changing or overthrowing the constitutional order (10 years prison). For attempts to introduce multilingualism at the official level in Ukraine, punishment of 10 years in prison is also expected;

6) The deployment of nationalist propaganda and the revision of the history of the Second World War. The best sample here is also Ukraine where in 2015 was accepted the Law "On the legal status and respect for the memory of the fighters for Ukraine's independence in the twentieth century", ${ }^{14}$ which was glorified the members of right-wing militaristic organizations that collaborated collectively or individually with the Nazi regime, who fought against the countries of the anti-Hitler coalition, for example the Ukrainian Insurgent Army. Article 6 of this Law established that persons who publicly show disdain for these fighters for the independence of Ukraine or deny their role in this struggle are criminally liable in accordance with the current legislation of Ukraine. Official Glorification of the executioners of the Jewish people means that Ukraine actually revived the state Anti-Semitism. May be there is not direct Anti-Semitism, but it is indirect Anti-Semitism, because all of this insult the Jews. Should we than be surprised by the growth of cases of public antiSemitism, the desecration of Jewish cemeteries and monuments to the victims of the Holocaust in Ukraine?

7) The declaration of formal inequality between the majority and the minority. The best sample here is the new Preamble to the Latvian Constitution adopted in 2014, ${ }^{15}$ which states that Latvia was created for the successful development and prosperity of the Latvian ethnos in order to guarantee the existence and development of Latvian culture and language. Nothing about the other ethnoses historically living in Latvia, their rights to their culture there was not said.

This is an absolutely radical agenda. This process undoubtedly contributed to the growth of the influence of right-wing radical organizations. The authorities either did not notice their activity, or just secretly promoted these activities. Because the goals of the radicals and the authorities at that moment were absolutely coincided. It turns out to be a paradox - on the one hand, the post-Soviet countries tried to form a European ethno-cultural model of a National State. This model involves the creation of Nation based on the ethnic and cultural values of the ethnic majority. But on the other hand, unlike in Europe, this process did not take place in conditions of culturally homogeneous societies with the gradual development of immigration processes. In these countries, this process took place in conditions of multi-ethnic and multicultural societies, in the conditions of failure from the old ideological model of society, implying the equality of all ethnic and other social groups. This led to the division of society along ethnic lines. Moreover, it has led to the emergence of dangerous trends, which can be described as a "modern racism".

Back in 1954, an American psychologist, author of the Theory of Personality Traits, Dr. Gordon Allport, that Cultural Racism arises when "one group declares its claim to determine cultural values for the whole society." The "modern racism" is not about the Race. It is about the culture. In the discourse of modern Racism, it is believed that different racial and ethnic groups with different cultural codes have no chance to get along with each other. and because of it, it is necessity the limitation of the influence of a minority culture upon the culture of the indigenous majority is generally accepted. Three methods are commonly used for this:
1) Restricting the flow of people of other cultures into the country, including restricting immigration in order to limit the cultural influence of a minority. ${ }^{16}$

2) Reducing the presence of representatives of another culture in the country. Variety of economic, political or cultural-educational tools is used for this purpose, forcing undesirable people of another culture to leave the country.

3) Forced cultural assimilation of minorities. Being a declared benefit for the national minority, it is replaced by the word "integration" more and more often. ${ }^{17}$ Although integration is a two-way street, assimilation is always a movement in one direction-towards the majority.

As we see, all this or almost all of this has a place in the new post-Soviet countries. As a rule, these countries rushed to announce that they had made an "European choice", implying that they refused to come closer to Russia. But they professed no European values at all. They need the brand "European choice" because they believe that countries made a European choice cannot be an object of criticism for violating minority rights.

Thus, right-wing radicals in these countries found themselves in an objectively favorable environment, which had been created during the last twenty five years. Today part of them is in parliaments. There are the radical right Party "All - to Latvia" in Latvia (7 years in the ruling Coalition), Conservative People's Party of Estonia (new Party of ruling Coalition), Union of Lithuanian Nationalists, Freedom Party and C14 in Ukraine, National Unity Party in Moldova, etc. Today, their goal is to bring to a logical end the policy of ousting or assimilating of national minorities. And it seems that large political parties - their partners in the ruling coalition-are afraid to object to right-wing radicals, because they are afraid to lose the support of their voters, who vote now on ethnic grounds. Thus, radical ideas became a system-forming factor in the formation of new states in the postSoviet space. The ruling elites in these countries tend to actively adopt radical ideas. There is a gradual merging of the elite and radical organizations. There is the last question-and what is in Russia? Russia differs from other countries not only in its size and population, but also in the level of multi-ethnicity. But this is the topic of another research.

\section{Acknowledgments}

None.

\section{Conflicts of interest}

The author declares there are no conflicts of interest.

\section{References}

1. Leonid Kuchma. Ukraine-not Russia. Ukraine: Publishing House Time; 2003. $14 \mathrm{p}$.

2. Michael Dubakov. $\mathrm{X}$ and say that it is not connected with the autopilot. 2003.

3. What were the Volhynian Massacres? 1943.

4. Français Español. Introduction: what is babi yar? Holocaust Library. 1989. pp. $168-173$.

5. Sue Surkes. Statue of nationalist blamed for pogroms against Jews is unveiled in Ukraine. 2017. 
6. H-Net's networks have moved to the H-Net commons. 2019. 905 p.

7. Lynn M Tesser. The Impact of the Post-Cold War European Minority Rights Regime on Inter-Ethnic Relations in Estonia and Latvia. 2016. 23 p.

8. https://en.wikipedia.org/wiki/Non-citizens_(Latvia)

9. Ending Childhood Statelessness: A Study on Estonia. 2014. 20 p.

10. Ukraine’s Poorly Timed Education Law. 2017.

11. Minority education attacked in Latvia: 2018 amendments to education laws. 2018. 12 p.

12. Vasyl Nimchenko. Discrimination of citizens on language basis is betrayal of national interests of the country. 2019.
13. On ensuring the functioning of the Ukrainian language as a state language. 2018.

14. Maria Mälksoo. Ukraine's Decommunisation Laws: A Hard Case for the EU Policy on Transitional Justice? 2017. pp.1-44.

15. Arianna Angeli. Latvia. A new preamble to the constitution adopted. NAD 2014;1(1):15-20.

16. Allport GW. The Nature of Prejudice. USA: Addison-Wesley Company; 1949. $11 \mathrm{p}$.

17. Saeima ceremonial sitting of 4 May 2019 in honour of the 29th anniversary of the restoration of the independence of the Republic of Latvia. 2019. 